\title{
EFFECT OF DIFFERENT STOCKING DENSITY TO GROWTH RATE OF CATFISH (Clarias gariepinus, Burch) CULTURED IN BIOFLOC ${ }^{\circledR}$ AND NITROBACTER MEDIA
}

\author{
Elfa Verda Puspita ${ }^{1}$ - Ratih Purnama Sari ${ }^{1}$
}

\begin{abstract}
Catfish is one of the freshwater commodities whose demand continues to increase in Indonesia. Intensive cultivation is done to meet market demand. Intensive cultivation is done by optimizing stocking density. The aim of this research was to know the effect of different density on feed productivity, growth, feed conversion ratio (FCR) and survival of catfish dumbo fry (Clarias gariepinus, Burch) in biofloc and nitrobacter media. This study used a completely randomized design (RAL) with 6 treatments and 3 replications. The test animals used catfish dumbo (Clarias gariepinus, Burch) with an average weight of 0,6 $\pm 0,1 \mathrm{~g}$ and an average length of $4 \mathrm{~cm}$. Catfish dombo seeds are kept in tarpaulin ponds $2 \mathrm{~m}$ in diameter with water volume $\pm 1 \mathrm{~m} 3$ for 45 days and feeding $3 \%$ of biomass weight. The results showed that the different density of stocking in biofloc and nitrobacter media had increase on productivity, specific growth rate, feed efficiency and no significant effect on the survival of catfish dumbo fry.
\end{abstract}

Keywords catfish, growth rate, bioflock, nitrobacter

Received : 31 Oktober 2017

Accepted : 27 Desember 2017

\footnotetext{
$\left.{ }^{1}\right)$ Akademi Perikanan Bhima Sakti. E-mail: elfa.verda@gmail.com
}

\section{PENDAHULUAN}

Ikan lele merupakan salah satu spesies ikan air tawar yang mengandung sumber protein hewani dan bernilai ekonomis. Lele telah menjadi salah satu bahan pangan komoditas perikanan yang diminati di Indonesia. Kebutuhan sumber protein hewani khususnya komoditas perikanan terus meningkat setiap tahunnya sehingga perlu adanya inovasi agar produksi meningkat. Produksi lele dumbo di Indonesia pada tahun 2005-2010 yaitu tahun 2005 sebesar 69.386 ton, tahun 2006 sebesar 77.332 ton, tahun 2007 sebesar 91.735 ton, tahun 2008 sebesar 114.317 ton, tahun 2009 sebesar 144.755 ton, dan tahun 2010 sebesar 273.554 ton (DJPB, 2010). Intensifikasi merupakan salah satu alternatif untuk meningkatkan produksi komoditas perikanan yang didasarkan dengan meningkatkan padat penebaran dengan penggunaan lahan yang terbatas, manajemen lingkungan yang baik dan penggunaan pakan buatan.

Intensifikasi budidaya khususnya peningkatan padat penebaran membawa dampak kurang baik terhadap kelestarian dan kesehatan lingkungan yang berupa penurunan kualitas lingkungan budidaya. Penurunan kualitas lingkungan disebabkan limbah organik dari sisa pakan dan kotoran, limbah tersebut umumnya didominasi oleh senyawa nitrogen anorganik yang beracun. Menurut De Schryver et al. (2008) tingginya penggunaan pakan buatan berprotein tinggi pada budidaya intensif menyebabkan pencemaran lingkungan budidaya dan memberi peluang terjadinya penyakit. Teknologi bioflok menjadi salah satu 
alternatif pemecah masalah limbah budidaya intensif. Teknologi ini paling menguntungkan karena selain dapat menurunkan limbah nitrogen anorganik dari sisa pakan dan kotoran, juga dapat menyediakan pakan tambahan berprotein untuk hewan budidaya sehingga dapat menaikkan pertumbuhan dan efisiensi pakan. Teknologi bioflok dilakukan dengan menambahkan karbon organik kedalam media pemeliharaan untuk meningkatkan rasio $\mathrm{C} / \mathrm{N}$ di media dan merangsang pertumbuhan bakteri heterotrof yang dapat mengasimilasi nitrogen anorganik menjadi biomass bakteri (Crab et al., 2007). Teknologi bioflok terbukti sangat bermanfaat pada budidaya ikan, baik secara ekonomis maupun ekologis (De Schryver et al., 2008; Crab et al., 2007).

Teknologi Nitrobacter sering juga digunakan pada ikan dengan padat penebaran tinggi. Menurut Kordi and Ghufran (2012) secara biologis, di alam sebenarnya dapat terjadi perombakan ammonia menjadi nitrat $\left(\mathrm{NO}_{3}\right)$, suatu bentuk yang tidak berbahaya dalam proses nitrifikasi, terutama bakteri Nitrosomonas dan Nitrobacter. Meskipun demikian tingginya kadar amoniak di dalam budidaya intensif memberikan gambaran bahwa jumlah Nitrobacter yang ada masih belum dapat mengimbangi jumlah amoniak yang dihasilkan. Oleh karena itu penambahan Nitrobacter dalam sistem budidaya intensif diharapkan mampu memperbaiki kualitas air akibat kepadatan ikan yang tinggi sehingga dapat meningkatkan pertumbuhan dan produksi ikan.

Teknologi bioflok dan Nitrobacter merupakan teknologi yang mampu membuat tingkat polusi air menurun sehingga diharapkan kualitas air menjadi baik. Pada penelitian ini dilakukan pengujian teknologi bioflok dan Nitrobacter dengan padat tebar yang berbeda pada ikan lele dumbo (C. gariepinus, Burch). Penelitian ini dilakukan sebagai pengembangan ilmu terkait padat tebar lele dumbo (C. gariepinus, Burch) dan pengembangan informasi bagi petani budidaya.

\section{MATERI DAN METODE}

Penelitian dilaksanakan dalam rancangan acak lengkap (RAL) dengan 6 perlakuan dan 3 ulangan. Perlakuan yang diujikan adalah padat tebar berbeda dalam media bioflok A (1500 ekor/ $\left.\mathrm{m}^{3}\right)$, B (1000 ekor/ $\left.\mathrm{m}^{3}\right)$, dan C (500 ekor/m $\left.\mathrm{m}^{3}\right)$, serta dalam media nitrobacter D (1500 ekor/m $\left.\mathrm{m}^{3}\right), \mathrm{E}$ $\left(1000\right.$ ekor $\left./ \mathrm{m}^{3}\right)$, dan F (500 ekor $\left./ \mathrm{m}^{3}\right)$. Benih ikan lele dumbo (C. gariepinus, Burch) dengan bobot rata-rata individu sebesar $0,6 \mathrm{~g}$ dan panjang rata-rata $4 \mathrm{~cm}, \mathrm{EM} 4{ }^{\circledR}$ yang terdiri dari bakteri Lactobacillus casei dan Saccharomyces cerevisiae, bakteri Nitrobacter, molase, dolomit, ragi tape, ragi tempe, pelet, suplemen dan obatobatan. Parameter yang diamati dalam penelitian ini adalah produktifitas, pertumbuhan, rasio konversi pakan (FCR) dan kelulushidupan.

Wadah pemeliharaan yang digunakan berupa kolam terpal berbentuk lingkaran dengan diameter 2 m sebanyak 6 buah. Volume air pada masing-masing wadah $\pm 1 \mathrm{~m}^{3}$ dengan padat tebar berbeda pada tiap perlakuan. Pakan yang diberikan adalah pakan apung pellet komersial PF-1000 dengan kandungan protein 39-40\%. Pakan diberikan sebanyak 3\% dari biomassa lele. Sumber karbon yang digunakan adalah molase (Purnomo, 2012).

Bakteri heterotrof yang digunakan adalah EM4 dengan komposisi bakteri Lactobacillus casei dan Saccharomyces cerevisiae. Dosis penambahan inokulasi bakteri sebesar $10 \mathrm{~mL} / \mathrm{m}^{3}$ dan dilakukan penambahan berkala tujuh hari sekali selama masa pemeliharaan. Variabel yang diamati meliputi produksi, laju pertumbuhan spesifik, kelulushidupan, rasio konversi pakan dan kualitas air.

Laju pertumbuhan spesifik harian (specific growth rate/SGR) ikan dihitung dengan menggunakan rumus (1) (Jauncey, 1998) ; Produktivitas budidaya per meter persegi luas dihitung menggunakan rumus (2) (Rohmana, 2009); Nilai kelulushidupan (Survival rate/SR) diketahui dengan menghitung jumlah ikan yang mati setiap hari, sehingga dapat diketahui ikan yang hidup, nilai kelulushidupan dapat dihitung dengan rumus (Effendie, 1997). Nilai rasio konversi pakan dihitung dengan cara menghitung jumlah pakan yang diberikan selama masa pemeliharaan, dibandingkan dengan pertambahan biomassa selama masa pemeliharaan, FCR dihitung dengan rumus (Stickney et al., 1979).

$S G R=\frac{\ln W_{t}-\ln W_{0}}{t} \times 100 \%$ 
dimana, $\mathrm{W}_{t}$ adalah berat rata rata pada waktu $\mathrm{t} ; \mathrm{W}_{0}$ adalah berat rata rata pada $\mathrm{t}=0$

Produksigr $/ m^{2}=\frac{W_{t}-W_{0}}{L}$

dimana $\mathrm{L}$ adalah luas kolam $\left(\mathrm{m}^{2}\right)$

$S R=\frac{N_{t}}{N_{0}} \times 100 \%$

dimana, $\mathrm{N}_{t}$ adalah jumlah total populasi pada waktu $\mathrm{t}$, dan $\mathrm{N}_{0}$ adalah jumlah populasi pada $\mathrm{t}$ $=0$

$F C R=\frac{\sum \text { pakandikonsumsi }}{\Delta \text { biomasa panen }}$

Pengukuran parameter kualitas air meliputi oksigen terlarut (DO), $\mathrm{pH}$, dan suhu. Pengukuran kualitas air dilakukan secara in situ, oksigen dan suhu diukur setiap hari dengan alat DO meter, $\mathrm{pH}$ diukur setiap minggu menggunakan $\mathrm{pH}$ meter.

\section{HASIL DAN PEMBAHASAN}

Hasil penelitian (Tabel 1) menunjukkan bahwa laju pertumbuhan spesifik (SGR) benih lele dumbo pada setiap perlakuan berbeda nyata $(\mathrm{P}<0,05)$. Laju pertumbuhan spesifik tertinggi pada perlakuan $\mathrm{C}$ (media bioflok) dan $\mathrm{F}$ (media nitrobacter) dengan padat tebar 500 ekor $/ \mathrm{m}^{3}$. Hal ini sesuai dengan pendapat Hermawan et al. (2014) SGR tertinggi dengan padat penebaran 500 ekor $/ \mathrm{m}^{3}$ dan SGR terendah pada padat penebaran 1500 ekor/ $\mathrm{m}^{3}$. Hal ini dikarenakan semakin tinggi kepadatan ikan maka ruang gerak akan semakin sempit dan kesempatan untuk memperoleh makanan juga semakin kecil sehingga laju pertumbuhan menurun seiring dengan bertambahnya padat penebaran.

Menurut Handajani and Hastuti (2002) makin tinggi kepadatan ikan akan mempengaruhi tingkah laku dan fisiologi ikan terhadap ruang gerak yang menyebabkan pertumbuhan, pemanfaatan makanan dan kelulushidupan mengalami penurunan. Begitu pula Sidik et al. (2002) menyatakan bahwa pertumbuhan ikan menurun dengan meningkatnya padat penebaran. Perbedaan padat tebar 5-20 ekor $/ \mathrm{m}^{2}$ menyebabkan pertumbuhan semakin menurun, penurunan pertumbuhan terjadi karena persaingan baik ruang gerak, oksigen terlarut maupun pakan (Nurlaela et al., 2017).

Hasil penelitian menunjukkan bahwa perbedaan padat tebar memberikan pengaruh nyata $(\mathrm{P}<0,05)$ terhadap produksi lele dumbo. Produksi lebih besar yang dicapai oleh perlakuan A $\left(1500 / \mathrm{m}^{3}\right)$ dan D $\left(1500 / \mathrm{m}^{3}\right)$ disebabkan karena produksi dihasilkan dari berat organisme budidaya dikalikan dengan padat tebar pada media budidaya, sehingga semakin tinggi padat tebar budidaya akan menghasilkan produksi lebih banyak. Menurut Hermawan et al. (2014), peningkatan padat penebaran pada budidaya lele intensif sistem bioflok dapat meningkatkan produksi budidaya lele sebesar 46-69\%.

Memproduksi ikan berarti mempertahankan ikan agar tetap hidup, tumbuh dan berkembang biak dalam waktu sesingkat mungkin hingga mencapai ukuran pasar dan bisa dijual. Pertumbuhan ikan akan menurun seiring dengan kepadatan yang meningkat, akan tetapi produksi tertinggi dicapai saat kepadatan yang tinggi. Oleh karena itu kepadatan dalam kaitannya dengan produksi harus menyeimbangkan antara efisiensi biologi dengan efisiensi ekonomi, sehingga dapat dihasilkan kepadatan optimal yang menghasilkan produksi maksimal Effendi (2004). Hasil penelitian Yuniarti (2006), menunjukkan bahwa hasil produksi meningkat seiring dengan peningkatan padat penebaran.

FCR digunakan untuk mengetahui tingkat konversi pakan yang dikonsumsi terhadap kenaikan pertumbuhan biomass ikan. Nilai FCR kecil menunjukkan pakan yang dikonsumsi ikan lebih efisien untuk pertumbuhan. Hasil analisis ragam menunjukkan perbedaan padat tebar memberikan pengaruh nyata $(\mathrm{P}<0,05)$ terhadap Rasio Konversi Pakan (FCR). FCR terendah pada perlakuan F media nitrobacter dengan padat tebar $500 \mathrm{ekor} / \mathrm{m}^{3}$. Hal ini diduga bahwa faktor perbedaan ruang gerak yang semakin sempit menyebabkan kompetisi dalam mencari makan, sehingga pemberian pakan lebih efektif pada kepadatan lebih rendah. Hasil penelitian Hermawan et al. (2014) menunjukkan bahwa tingkat efisiensi pakan tertinggi diperoleh pada padat penebaran lele 500 ekor $/ \mathrm{m}^{3}$ dibandingkan dengan kepa- 
Table 1 Hasil pengamatan variabel selama penelitian

\begin{tabular}{ccccc}
\hline & \multicolumn{4}{c}{ Variabel } \\
\cline { 2 - 5 } Perlakuan & $\begin{array}{c}\text { Laju Pertumbuhan Spesifik (SGR) } \\
(\% / \text { hari })\end{array}$ & $\begin{array}{c}\text { Produksi } \\
\left(\mathrm{g} / \mathrm{m}^{2}\right)\end{array}$ & $\begin{array}{c}\text { Rasio konversi pakan } \\
(\mathrm{FCR})\end{array}$ & $\begin{array}{c}\text { Kelulushidupan (SR) } \\
(\%)\end{array}$ \\
\hline A & $5,16 \pm 0,37^{c d}$ & $10098,37 \pm 0,32^{a}$ & $1,00 \pm 0,00^{b}$ & $93,43 \pm 0,29^{a b}$ \\
B & $5,91 \pm 0,89^{b c}$ & $8407,37 \pm 0,19^{b}$ & $0,91 \pm 0,00^{d}$ & $87,33 \pm 1,45^{a b}$ \\
C & $7,10 \pm 0,23^{a}$ & $5746,50 \pm 0,2^{c}$ & $0,99 \pm 0,00^{c}$ & $78,87 \pm 6,78^{b}$ \\
D & $6,20 \pm 0,39^{b}$ & $8828,20 \pm 0,15^{d}$ & $1,15 \pm 0,00^{a}$ & $95,00 \pm 2,89^{a}$ \\
E & $4,47 \pm 0,14^{d}$ & $7459,53 \pm 0,2^{a}$ & $1,02 \pm 0,00^{b}$ & $86,63 \pm 3,32^{a b}$ \\
F & $7,44 \pm 0,18^{a}$ & $6415,27 \pm 0,15^{f}$ & $0,89 \pm 0,00^{e}$ & $94,77 \pm 0,79^{a}$ \\
\hline
\end{tabular}

Ket; Nilai rerata pada kolom yang sama dengan huruf berbeda menunjukkan perbedaan secara signifikan $(\mathrm{p}<0,05)$.

A : Media bioflok A (1500 ekor $\left./ \mathrm{m}^{3}\right)$

B : Media bioflok B $\left(1000 \mathrm{ekor} / \mathrm{m}^{3}\right)$

C : Media bioflok C (500 ekor $/ \mathrm{m}^{3}$ )

D : Media Nitrobacter D $\left(1500 \mathrm{ekor} / \mathrm{m}^{3}\right)$

E : Media Nitrobacter E $\left(1000 \mathrm{ekor} / \mathrm{m}^{3}\right)$

F : Media Nitrobacter F (500 ekor $\left./ \mathrm{m}^{3}\right)$

datan 1500 ekor/m³ $\mathrm{m}^{3}$. Hasil penelitian Yuniarti (2006) menunjukkan bahwa tingkat efisiensi pakan tertinggi diperoleh pada padat penebaran 400 ekor $/ \mathrm{m}^{2}$ dibandingkan dengan padat penebaran 800 ekor/m $\mathrm{m}^{2}$ dan 1200 ekor $/ \mathrm{m}^{2}$. Pada kepadatan rendah, ikan mampu memanfaatkan pakan lebih efisien dibanding dengan kepadatan yang lebih tinggi karena persaingan yang terjadi cenderung lebih rendah (Unisa, 2000).

Hasil analisis ragam menunjukkan bahwa benih lele dumbo yang dipelihara pada media bioflok dengan padat tebar yang berbeda tidak menunjukkan perbedaan $(\mathrm{P}>0,05)$, begitu pula pada ikan lele dumbo yang dipelihara pada media nitrobacter dengan padat tebar berbeda. Hanya saja ada perbedaan antara perlakuan $\mathrm{C}$ (bioflok 500 ekor $/ \mathrm{m}^{3}$ ) kelulushidupan paling rendah, diduga dikarenakan kanibalisme antar ikan. Kelulushidupan yang didapatkan dalam penelitian ini cukup tinggi. Hal ini sesuai dengan penelitian Hermawan et al. (2014) yang menunjukkan bahwa tingkat kelulushidupan lele $>94 \%$ dan tingkat kelulushidupan tidak dipengaruhi oleh kepadatan lele. Hal ini dimungkinkan karena kualitas air pada media pemeliharaan masih layak untuk menunjang kelulushidupan lele. Perlakuan padat tebar 60, 75 dan 90 ekor/l ikan tidak berpengaruh terhadap kelulushidupan ikan (Irliyandi, 2008). Penelitian Unisa (2000) menunjukkan bahwa padat tebar benih lele dumbo dengan bobot dan panjang rata-rata adalah $1,34 \mathrm{~g}$ dan $5,23 \mathrm{~cm}$ yang dipelihara dalam sistem resirkulasi dengan padat penebaran berbeda memiliki nilai kelulushidupan yang tinggi $(99,70 \%)$.
Table 2 Nilai rataan dan kisaran kualitas air

\begin{tabular}{cccccc}
\hline \multirow{2}{*}{ Parameter } & \multicolumn{5}{c}{ Perlakuan } \\
\cline { 2 - 6 } & $\mathrm{A}$ & $\mathrm{B}$ & $\mathrm{C}$ & $\mathrm{D}$ & $\mathrm{E}$ \\
\hline $\mathrm{pH}$ & 7,2 & 7,5 & 7,3 & 7,4 & 7,5 \\
Suhu $\left({ }^{\circ} \mathrm{C}\right)$ & 27 & 26 & 26 & 27 & 27 \\
$\mathrm{DO}(\mathrm{mg} / \mathrm{L})$ & 0,4 & 1,3 & 1,0 & 0,5 & 0,4 \\
\hline
\end{tabular}

Hasil pengamatan kualitas air (Tabel 2) menunjukkan bahwa kualitas air masih dalam kondisi baik untuk budidaya ikan lele dumbo $(C$. gariepinus). Hasil pengukuran suhu air kisaran 26- $27^{\circ} \mathrm{C}$ pada setiap perlakuan, suhu tersebut masih dalam kisaran suhu optimal. Hermawan et al. (2014) kisaran suhu optimal untuk budidaya lele adalah $25^{\circ} \mathrm{C}-30^{\circ} \mathrm{C}$. Oksigen terlarut rata-rata penelitian yakni $0,4-1,3 \mathrm{mg} / \mathrm{L}$. Nilai kisaran oksigen terlarut untuk pemeliharaan lele dumbo minimal $3 \mathrm{mg} / \mathrm{L}$ (DJPB, 2010). Nilai $\mathrm{pH}$ air pada setiap perlakuan dalam kisaran optimum untuk budidaya ikan, nilai rata-rata $\mathrm{pH}$ pada setiap perlakuan selama penelitian 7,27,5. Mahyudin (2008) menyatakan bahwa nilai $\mathrm{pH}$ optimal untuk budidaya lele pada kisaran 6,5-8,5.

\section{SIMPULAN}

Dari hasil penelitian dapat disimpulkan bahwa padat tebar yang berbeda dalam media bioflok dan nitrobacter dapat meningkatkan produktivitas, laju pertumbuhan spesifik, dan efisiensi pakan serta tidak berpengaruh terhadap kelulushidupan benih lele. 


\section{References}

Crab, R., Avnimelech, Y., Defoirdt, T., Bossier, P., and Verstraete, W. (2007). Nitrogen removal techniques in aquaculture for a sustainable production. Aquaculture, 270(14):1-14.

De Schryver, P., Crab, R., Defoirdt, T., Boon, N., and Verstraete, W. (2008). The basics of bio-flocs technology: the added value for aquaculture. Aquaculture, 277(3-4):125137.

DJPB (2010). Tujuh provinsi penghasil ikan lele dumbo di indonesia. Technical report, Direktorat Jendral Perikanan Budidaya.

Effendi, I. (2004). Pengantar akuakultur. Penebar Swadaya. Jakarta, 188.

Effendie, M. I. (1997). Biologi perikanan. Yayasan Pustaka Nusatama. Yogyakarta, 163.

Handajani, H. and Hastuti, S. (2002). Budidaya perairan. Bayu Media. Malang, 201.

Hermawan, T. E. S. A., Sudaryono, A., and Prayitno, S. B. (2014). Pengaruh padat tebar berbeda terhadap pertumbuhan dan kelulushidupan benih lele (clarias gariepinus) dalam media bioflok. Journal of Aquaculture Management and Technology, 3(3):3542.

Irliyandi, F. (2008). Pengaruh padat penebaran 60, 75 dan 90 ekor/liter terhadap produksi ikan patin pangasius hypophthalmus ukuran 1 inci up $(3 \mathrm{~cm})$ dalam sistem resirkulasi.

Jauncey, K. (1998). Tilapia Feed and Feeding. Pisces Press.

Kordi, M. and Ghufran, M. (2012). Kiat sukses pembesaran lele unggul. Penerbit Andi. Yogyakarta.

Mahyudin, K. (2008). Panduan lengkap agribisnis Lele. Niaga Swadaya.

Nurlaela, I., Tahapari, E., and Sularto, S. (2017). Pertumbuhan ikan patin nasutus (pangasius nasutus) pada padat tebar yang berbeda. In Prosiding Forum Inovasi Teknologi Akuakultur, pages 31-36.

Purnomo, P. D. (2012). Pengaruh penambahan karbohidrat pada media pemeliharaan melalui teknologi bioflok terhadap produksi budidaya intensif nila (oreochromis niloticus). Master's thesis, Fakultas Perikanan dan Ilmu Kelautan. Universitas Diponegoro.
Rohmana, D. (2009). Konversi limbah budidaya ikan lele, clarias sp. menjadi biomassa bakteri heterotrof untuk perbaikan kualitas air dan makanan udang galah, macrobrachium rosenbergii.

Sidik, A. S., Sarwono, and Agustina (2002). Pengaruh padat penebaran terhadap laju nitrifikasi dalam budidaya ikan sistem resirkulasi tertutup. Jurnal Akuakultur Indonesia, 1(2):47-51.

Stickney, R. R. et al. (1979). Principles of warmwater aquaculture. John Wiley \& Sons.

Unisa, R. (2000). Pengaruh padat penebaran ikan terhadap pertumbuhan dan kelangsungan hidup ikan lele dumbo (clarias $\mathrm{sp}$ ) dalam sistem resirkulasi dengan debit air 33 lpm/m3. Skripsi. Jurusan Budidaya Perairan. Fakultas Perikanan dan Ilmu Kelautan. IPB. Bogor.

Yuniarti (2006). Pengaruh kepadatan benih ikan lele dumbo (clarias gariepinus) terhadap produksi pada sistem budidaya dengan pengendalian nitrogen melalui penambahan tepung terigu. Master's thesis, Fakultas Perikanan Dan Ilmu Kelautan, Institut Pertanian Bogor. 
